\title{
TINJAUAN YURIDIS TENTANG PUTUSAN PERKARATINDAK PIDANA KORUPSI DAN AKIBAT HUKUMNYABAGI TERDAKWA YANG BERSTATUS KEPALA DESA
}

(Studi di Pengadilan Negeri Lamongan)

\author{
M. Yanto, S.H., M.H \\ muhamadyanto622@unisla.ac.id \\ Universitas islam lamongan
}

\begin{abstract}
Abstrak
Dalam banyak hal, penyebab seseorang melakukan korupsi adalah karena ketergodaannya akan dunia materi atau kekayaan yang tidak mampu ditahannya. Ketika dorongan untuk menjadi kaya tidak mampu ditahan sementara akses ke arah kekayaan bisa diperoleh melalui cara berkorupsi, maka jadilah seseorang akan melakukan korupsi. Jadi, jika menggunakan cara pandang penyebab korupsiseperti ini, maka salah satu penyebab korupsi adalah cara pandang terhadap kekayaan. Cara pandang terhadap kekayaan yang salah akan menyebabkan cara yang salah dalam mengakses kekayaan. Korupsi demikian kiranya akan terus berlangsung, selama masih terdapat kesalahan tentang cara memandang kekayaan. Semakin banyak orang salah dalam memandang kekayaan, maka semakin besar pula kemungkinan orang akan melakukan kesalahan dalam mengakses kekayaan. Tujuan penelitian ini adalah:Untuk mengetahui aturan tindak pidana korupsi menurut Undang-Undang RI Nomor 31 Tahun 1991 tentang pemberantasan tindak pidana korupsi sebagaimana telah diubah dengan UU No.20 Tahun 2001 dan Untuk mengetahui akibat hukum bagi terdakwa tindak pidana korupsi yang berstatus Kepala Desa. Karena korupsi sudah merambah ke kawasan pedesaan.Jenis penelitian dalam penulisan ini adalah penelitian hukum empiris, yaitu penelitian lapangan yang memerlukan atau memakai data primer sebagai data utama dan di dukung dengan data sekunder yang di lakukan dengan cara wawancara, yaitu melakukan Tanya jawab secara langsung dan terstruktural personalia terkait dengan penelitian ini. Dan sumber bahan hukum yang dipakai adalah Bahan hukum primer, yakni Undang-Undang Hukum Pidana terkait dengan pidana korupsi, Undang-Undang Nomor 31 Tahun 1999 tentang pemberantasan tindak pidana korupsi, sebagaimana telah diubah dengan Undang-Undang Nomor 20 Tahun 2001 dan Putusan Pengadilan yang terkait dengan tindak pidana korupsi. Bahan hukum Sekunder diperoleh melalui studi kepustakaan yakni dengan mempelajari buku-buku, peraturan perundang-undangan serta dokumen-dokumen, pendapat para ahli hukum, hasil kegiatan ilmiah bahkan data yang bersifat publik yang berhubungan dengan penulisan. Korupsi bisa dilihat dari perspektif kebudayaan. Secara teoritis dan praktis, relasi antara korupsi dan kebudayaan sangat kuat. Bahkan dalam praktiknya, korupsi terkait dengan unsur tradisi feodalisme, hadiah, upeti, dan sistem kekerabatan (extended family). Korupsi agaknya akan tumbuh dalam masyarakat atau bangsa yang memiliki tradisi budaya feodalis atau neofeodalis. Pasalnya, dalam budaya tersebut, tidak ada sistem nilai yang memisahksan secara tajam antara milik publik (Negara) dengan milik pribadi bagi ruling class (elit penguasa). Sedangkan, sistem kekerabatan ikut mendorong nepotisme.
\end{abstract}

Kata Kuci : korupsi, kebudayaan, putusan hakim.

\section{PENDAHULUAN}

\section{Latar Belakang Masalah}

Manusia dewasa ini sedang hidup di tengah kehidupan material yang sangat mengedepankan uang. Dunia kapitalistik memang ditandai salah satunya ialah akumulasi modal atau kepemilikan yang semakin banyak. Semakin banyak modal atau akumulasi modal maka semakin dianggap sebagai orang yang kaya atau orang yang berhasil. Maka ukuran orang disebut sebagai kaya atau berhasil adalah ketika yang bersangkutan memiliki sejumlah kekayaan yang kelihatan di dalam kehidupan sehari-hari. Ada outward appearance yang tampak di dalam kehidupan sehari-harinya. Cobalah kalau kita berjalan di daerah-daerah yang tergolong daerah komunitas kaya, maka hal itu cukup dilihat dengan seberapa besar 
rumahnya, di daerah mana rumah tersebut, dan apa saja yang ada di dalam rumah tersebut. Di Indonesia, dengan mudah dapat diketahui bahwa ada perumahan yang tergolong sebagai perumahan "elit". Maka akan terpampangbagaimana rumah kaum elit di negeri ini. Dan itulah gambaran kesuksesan atau keberhasilan kehidupan.Di tengah kehidupan yang semakin sekular, maka ukurannya adalah seberapa besar seseorang bisa mengakses kekayaan. Semakin kaya, maka semakin berhasil. Maka ketika seseorang menempati suatu ruang untuk bisa mengakses kekayaan, maka seseorang akan melakukannya secara maksimal. banyak orang yang mudah tergoda dengan kekayaan. Karena persepsi tentang kekayaan sebagai ukuran keberhasilan seseorang, seseorang akan mengejar kekayaan itu tanpa memperhitungkan bagaimana kekayaan tersebut diperoleh.

Seiring dengan perkembangan zaman, kini Indonesia pun mengalami banyak perubahan, berawal dari zaman kerajaan, penjajahan, sekarang menjadiNegara berkembang, semua itu diraih dengan perjuangan yang begitu keras. Dengan semangat juang tinggi hari ini Indonesia telah dikenal sebagai Negara hukum, tetapi masih banyak yang harus diperbaiki, terutama mengenai pengamalan undang-undang yang telah susah payah dibuat oleh para anggota Dewan Perwakilan Rakyat (DPR).Pembangunan nasional bertujuan untuk mewujudkan masyarakat Indonesia seutuhnya yang adil, makmur, sejahtera, dan tertib berdasarkan Pancasila dan Undang-Undang Dasar 1945 selanjutnya disebut UUD 45. Untuk mewujudkan hal demikian tentu perlu secara terus menerus ditingkatkan usahausaha pencegahan dan pemberantasan tindak pidana pada umumnya dan pada pidana korupsi khususnya.

Korupsi pertama kali dianggap sebagai tindak pidana di Indonesia berdasarkan Undang-Undang No. 24 Prp. Tahun 1960 tentang Pengusutan, Penuntutan, dan Pemeriksaan Tindak Pidana Korupsi. Dalam kenyataannya undang-undang ini tidak mampu melaksanakan tugasnya sehingga dicabut dandiganti dengan Undang-Undang No. 3 tahun 1971 tentang Pemberantasan Tindak Pidana Korupsi (PTPK), dan terakhir sejak tanggal 16 Agustus 1999 diganti dengan
Undang-Undang No. 31 Tahun 1999 tentang pemberantasan tindak pidana korupsi sebagaimana telah diubah dengan Undang-Undang No. 20 Tahun 2001.Dakwaan korupsi terhadap beberapa petinggi Negara memiliki persamaan prinsipil, yakni bahwa tindak pidana yang didakwakan tersebut berkaitan erat dengan jabatan yang disandang tatkala itu dilakukan. Jabatan (okupasi), yang didalamnya terkandung sejumlah power and authority (kekuasaan dan kewenangan), mejadi instrument utama dimungkinkannya kejahatan yang dituduhkan itu dapat dilaksanakan pelaku. Karena, hampir senantiasa bertalian dengan jabatan, maka tindak pidana korupsi sering pula dikelompokkan sebagai occupational crime (kejahatan jabatan), yakni kejahatan yang terlaksanakannya mensyaratkan adanya suatu jabatan atau jenis pekerjaan yang dilindungi undang-undang.

Dalam banyak hal, penyebab seseorang melakukan korupsi adalah karena ketergodaannya akan dunia materi atau kekayaan yang tidak mampu ditahannya. Ketika dorongan untuk menjadi kaya tidak mampu ditahan sementara akses ke arah kekayaan bisa diperoleh melalui cara berkorupsi, maka jadilah seseorang akan melakukan korupsi. Jadi, jika menggunakan cara pandang penyebab korupsiseperti ini, maka salah satu penyebab korupsi adalah cara pandang terhadap kekayaan. Cara pandang terhadap kekayaan yang salah akan menyebabkan cara yang salah dalam mengakses kekayaan. Korupsi demikian kiranya akan terus berlangsung, selama masih terdapat kesalahan tentang cara memandang kekayaan. Semakin banyak orang salah dalam memandang kekayaan, maka semakin besar pula kemungkinan orang akan melakukan kesalahan dalam mengakses kekayaan.

Maka dari itu Negara sangat rawan akan terjadinya tindak pidana korupsi. Banyak hal yang mengakibatkan terjadinya seorang aparatur Negara melakukan tindak pidana korupsi, antara lain:

1. Kurang memilikinya ketaqwaan terhadap Tuhan YME seperti yang di cantumkan dlm Undang-Undang Dasar 1945.

2. Karena ada peluang dalam jabatan dan wewenang. 
3. Kurang memilikinya rasa sosial terhadap masyarakat.

4. Lemahnya peraturan perundangundangan yang berlaku.

5. Lemahnya pengawasan terhadap aparatur atau kurang maksimalnya pengawasan dari pihak yang berwenang.

6. Kurang tepat dalam penempatan jabatan pada aparat yang ditunjuk karena tidak sesuai dengan disiplin ilmu yang dimiliki.

7. Lemahnya penindakan hukum.

8. Lemahnya fungsi Demokrasi dalam birokrasi yang mengakibatkan pegawai tunduk pada atasan atau pimpinan bukan tunduk pada Undang-Undang atau hukum positif.

Selanjutnya Proses pembuktian atau membuktikan mengandung maksud dan usaha untuk menyatakan kebenaran atas sesuatu peristiwa, sehingga dapat diterima akal terhadap kebenaran peristiwa tersebut.

\section{MetodePenelitian}

\section{Pendekatan Masalah}

Jenis penelitian dalam penulisan ini adalah penelitian hukum empiris, yaitu penelitian lapangan yang memerlukan atau memakai data primer sebagai data utama dan di dukung dengan data sekunder yang di lakukan dengan cara wawancara, yaitu melakukan Tanya jawab secara langsung dan terstruktural personalia terkait dengan penelitian ini.

\section{Sumber Bahan Hukum}

a) Bahan hukum primer, yakni Undang-Undang Hukum Pidana terkait dengan pidana korupsi, Undang-Undang Nomor 31 Tahun 1999 tentang pemberantasan tindak pidana korupsi, sebagaimana telah diubah dengan Undang-Undang Nomor 20 Tahun 2001 dan Putusan Pengadilan yang terkait dengan tindak pidana korupsi.

b) Bahan hukum Sekunder diperoleh melalui studi kepustakaan yakni dengan mempelajari buku-buku, peraturan perundang-undangan serta dokumen-dokumen, pendapat para ahli hukum, hasil kegiatan ilmiah bahkan data yang bersifat publik yang berhubungan dengan penulisan.

\section{HASIL DAN PEMBAHASAN}

Menurut Fockema Andrea kata korupsi awalnya berasal dari bahasa Latin, corruption atau corruptus (Webster Student Dictionary; 1960). Kata corruptio itu sendiri berasal dari kata corrumpere, suatu kata dalam bahasa Latin yang lebih tua. Dari bahasa Latin itulah lalu turun ke banyak bahasa Eropa seperti Inggris, yaitu corruption, corrupt; Perancis, yaitu corruption; dan Belanda, yaitu corruptive (korruptie). Patut diduga, istilah korupsi dalam Bahasa Indonesia berasal dari bahasa Belanda yaitu korupsi.

Istilah korupsi yang telah diterima dalam perbendaharaan kata bahasa Indonesia itu, dapat disimpulkan oleh poerwadarminta dalam KamusUmum Bahasa Indonesia: "korupsi ialah perbuatran yang buruk seperti penggelapan uang, penerimaan uang sogok dan sebagainya.

Di Malaysia terdapat juga peraturan korupsi. Disitu tidak dipakai kata korupsi melainkan dipakai kata resuah yang tentu berasal dari bahasa arab (riswah), yang menurut kamus Arab-Indonesia artinya korupsi.

Dengan pengertian korupsi yang sedemikian luas maka, secara harfiah korupsi merupakan sesuatu yang busuk, jahat, dan merusak. Jika membicarakan tentang korupsi memang akan menemukan kenyataan semacam itu karena korupsi menyangkut segi-segi moral, sifat keadaan yang busuk, jabatan karena pemberian, faktor ekonomi dan politik, serta penempatan kelurga atau golongan kedalam kedinasan di bawah kekusaan jabatnnya. Dengan demikian, secara harfiah dapat ditarik kesimpulan bahwa sesungguhnya istilah korupsi memiliki arti yang sangat luas. Antara lain:
1. Korupsi, penyelewengan atau penggelapan (uang negara atau perusahaan sebagainya) untuk kepentingan pribadi atau orang lain.

2. Korupsi : busuk; rusak; suka memakai barang atau uang yang dipercayaakan kepadanya; dapat disogok (melalui kekusaan untuk kepentingan pribadi).

Tindak Pidana Korupsi menurut UndangUndang Nomor 31 Tahun 1999 tentang tindak pidana korupsi sebagaimana telah diubah dengan Undang-Undang Nomor 20 Tahun 2001 adalah sebagai berikut : 
1. (Pasal 2 UU Nomor 31 tahun 1999)

Setiap orang yang secara melawan hukum melakukan perbuatan memperkaya diri sendiri atau orang lain atau suatu korporasi yang dapat merugikan keuangan Negara atau perekonomian Negara.

2. (Pasal 3 UU Nomor 31 tahun 1999). Setiap orang yang dengan tujuan menguntungkan diri sendiri atau orang lain atau suatu korporasi, menyalahgunakan kewenangan, kesempatan atau sarana yang ada padanya karena jabatan atau kedudukan yang dapat merugikan keuangan negara atau perekonomian Negara.

3. (Pasal 5 UU Nomor. 20 Tahun 2001).

Setiap orang atau pegawai negeri sipil/penyelenggara negara yang memberi atau menjanjikan sesuatu kepada pegawai negeri atau penyelenggara negara dengan maksud supaya pegawai negeri atau penyelenggara negara tersebut berbuat atau tidak berbuat sesuatu dalam jabatannya, yang bertentangan dengan kewajibannya; atau memberi sesuatu kepada pegawai negeri atau penyelenggara negara karena atau berhubungan dengan sesuatu yang bertentangan dengan kewajiban, dilakukan atau tidak dilakukan dalam jabatannya.

4. (Pasal 6 UU Nomor. 20 Tahun 2001)

Setiap orang yang memberi atau menjanjikan sesuatu kepada hakim dengan maksud untuk mempengaruhi putusan perkara yang diserahkan kepadanya untuk diadili; atau. memberi atau menjanjikan sesuatu kepada seseorang yang menurut ketentuan peraturan perundangundangan ditentukan menjadi advokat untuk menghadiri sidang pengadilan dengan maksud untuk mempengaruhi nasihat atau pendapat yang akan diberikan berhubung dengan perkara yang diserahkan kepada pengadilan untuk diadili.

5. Pasal 7 UU Nomor. 20 Tahun 2001:

a. Pemborong, ahli bangunan yang pada waktu membuat bangunan, atau penjual bahan bangunan yang pada waktu menyerahkan bahan bangunan, melakukan perbuatan curang yang dapat membahayakan keamanan orang atau barang, atau keselamatan negara dalam keadaan perang

b Setiap orang yang bertugas mengawasi pembangunan atau penyerahan bahan bangunan, sengaja membiarkan perbuatan curang yang dapat membahayakan keamanan orang atau barang, atau keselamatan negara dalam keadaan perang

c. Setiap orang yang pada waktu menyerahkan barang keperluan Tentara
Nasional Indonesia dan atau Kepolisian Negara Republik Indonesia melakukan perbuatan curang yang dapat membahayakan keselamatan negara dalam keadaan perang; atau

d. Setiap orang yang bertugas mengawasi penyerahan barang keperluan Tentara Nasional Indonesia dan atau Kepolisian Negara Republik Indonesia dengan sengaja membiarkan perbuatan curang yang dapat membahayakan keselamatan negara dalam keadaan perang.

e. Bagi orang yang menerima penyerahan bahan bangunan atau orang yang menerima penyerahan barang keperluan Tentara Nasional Indonesia dan atau Kepolisian Negara Republik Indonesia dan membiarkan perbuatan curang yang dapat membahayakan keamanan orang atau barang, atau keselamatan negara dalam keadaan perang atau yang dapat membahayakan keselamatan negara dalam keadaan perang.

6. (Pasal 8 UU Nomor. 20 tahun 2001)

Pegawai negeri atau orang selain pegawai negeri yang ditugaskan menjalankan suatu jabatan umum secara terus menerus atau untuk sementara waktu, dengan sengaja menggelapkan uang atau surat berharga yang disimpan karena jabatannya, atau membiarkan uang atau surat berharga tersebut diambil atau digelapkan oleh orang lain, atau membantu dalam melakukan perbuatan tersebut.

7. (Pasal 9 UU Nomor. 20 tahun 2001)

Pegawai negeri atau orang selain pegawai negeri yang diberi tugas menjalankan suatu jabatan umum secara terus menerus atau untuk sementara waktu, dengan sengaja memalsu buku-buku atau daftar-daftar yang khusus untuk pemeriksaan administrasi.

8. (Pasal 10 UU Nomor. 20 Tahun 2001)

Pegawai negeri atau orang selain pegawai negeri yang diberi tugas menjalankan suatu jabatan umum secara terus menerus atau untuk sementara waktu, dengan sengaja;

a. Menggelapkan, menghancurkan, merusakkan, atau membuat tidak dapat dipakai barang, akta, surat, atau daftar yang digunakan untuk meyakinkan atau membuktikan di muka pejabat yang berwenang, yang dikuasai karena jabatannya; atau

b. Membiarkan orang lain menghilangkan, menghancurkan, merusakkan, atau membuat tidak dapat dipakai barang, akta, surat, atau daftar tersebut; atau

c. Membantu orang lain menghilangkan, menghancurkan, merusakkan, atau 
membuat tidak dapat dipakai barang, akta, surat, atau daftar tersebut.

9. (Pasal 11 UU Nomor. 20 Tahun 2001)

Pegawai negeri atau penyelenggara negara yang menerima hadiah atau janji padahal diketahui atau patut diduga, bahwa hadiah atau janji tersebut diberikan karena kekuasaan atau kewenangan yang berhubungan dengan jabatannya, atau yang menurut pikiran orang yang memberikan hadiah atau janji tersebut ada hubungan dengan jabatannya .

10. Pasal 12 UU Nomor. 20 Tahun 2001 :

a. Pegawai negeri atau penyelenggara negara yang menerima hadiah atau janji, padahal diketahui atau patut diduga bahwa hadiah atau janji tersebut diberikan untuk menggerakkan agar melakukan atau tidak melakukan sesuatu dalam jabatannya, yang bertentangan dengan kewajibannya;

b. Pegawai negeri atau penyelenggara negara yang menerima hadiah, padahal diketahui atau patut diduga bahwa hadiah tersebut diberikan sebagai akibat atau disebabkan karena telah melakukan atau tidak melakukan sesuatu dalam jabatannya yang bertentangan dengan kewajibannya;

c. Hakim yang menerima hadiah atau janji, padahal diketahui atau patut diduga bahwa hadiah atau janji tersebut diberikan untuk mempengaruhi putusan perkara yang diserahkan kepadanya untuk diadili;

d. Seseorang yang menurut ketentuan peraturan perundang-undangan ditentukan menjadi advokat untuk menghadiri sidang pengadilan, menerima hadiah atau janji, padahal diketahui atau patut diduga bahwa hadiah atau janji tersebut untuk mempengaruhi nasihat atau pendapat yang akan diberikan, berhubung dengan perkara yang diserahkan kepada pengadilan untuk diadili;

e. Pegawai negeri atau penyelenggara negara yang dengan maksud menguntungkan diri sendiri atau orang lain secara melawan hukum, atau dengan menyalahgunakan kekuasaannya memaksa seseorang memberikan sesuatu, membayar, atau menerima pembayaran dengan potongan, atau untuk mengerjakan sesuatu bagi dirinya sendiri;

f. Pegawai negeri atau penyelenggara negara yang pada waktu menjalankan tugas, meminta, menerima, atau memotong pembayaran kepada pegawai negeri atau penyelenggara negara yang lain atau kepada kas umum, seolah-olah pegawai negeri atau penyelenggara negara yang lain atau kas umum tersebut mempunyai utang kepadanya, padahal diketahui bahwa hal tersebut bukan merupakanutang;

g. Pegawai negeri atau penyelenggara negara yang pada waktu menjalankan tugas, meminta atau menerima pekerjaan, atau penyerahan barang, seolah-olah merupakan utang kepada dirinya, padahal diketahui bahwa hal tersebut bukan merupakan utang;

h. Pegawai negeri atau penyelenggara negara yang pada waktu menjalankan tugas, telah menggunakan tanah negara yang di atasnya terdapat hak pakai, seolaholah sesuai dengan peraturan perundangundangan, telah merugikan orang yang berhak, padahal diketahuinya bahwa perbuatan tersebut bertentangan dengan peraturan perundangundangan; atau

i. Pegawai negeri atau penyelenggara negara baik langsung maupun tidak langsung dengan sengaja turut serta dalam pemborongan, pengadaan, atau persewaan, yang pada saat dilakukan perbuatan, untuk seluruh atau sebagian ditugaskan untuk mengurus atau mengawasinya.

11. (Pasal 12B UU Nomor. 20 Tahun 2001)

Setiap gratifikasi kepada pegawai negeri atau penyelenggara negara dianggap pemberian suap, apabila berhubungan dengan jabatannya dan yang berlawanan dengan kewajiban atau tugasnya.

12. (Pasal 13 UU Nomor. 31 Tahun 1999)

Setiap orang yang memberi hadiah atau janji kepada pegawai negeri dengan mengingat kekuasaan atau wewenang yang melekat pada jabatan atau kedudukannya, atau oleh pemberi hadiah atau janji dianggap melekat pada jabatan atau kedudukan.

13. (Pasal 14 UU Nomor. 31 Tahun 1999)

Setiap orang yang melanggar ketentuan Undang-undang yang secara tegas menyatakan bahwa pelanggaran terhadap ketentuan Undang-undang tersebut sebagai tindak pidana korupsi berlaku ketentuan yang diatur dalam Undang-undang ini. Di dalam Undang-Undang tindak pidana korupsi terdapat tiga istilah hukum yang perlu diperjelas, yaitu istilah tindak pidana korupsi, keuangan negara dan perekonomian negara. 
a. Tindak pidana korupsi dalam UndangUndang Nomor 31 Tahun 1999 adalah :

1. Setiap orang yang secara melawan hukum melakukan perbuatan memperkaya diri sendiri atau orang lain atau suatu korporasi yang dapat merugikan keuangan negara atau perekonomian negara;

2. Setiap orang yang dengan tujuan menguntungkan diri sendiri atau orang lain atau suatu korporasi, menyalahgunakan kewenangan, kesempatan atau sarana yang ada padanya karena jabatan atau kedudukan yang dapat merugikan keuangan negara atau perekonomian negara.

b. Pengertian Keuangan Negara adalah seluruh kekayaan negara dalam bentuk apapun baik yang dipisahkan maupun yang tidak dipisahkan, termasuk didalamnya segala bagian kekayaan negara dan segala hak dan kewajiban yang timbul karenanya :

1. Berada dalam penguasaan, pengurusan dan pertanggungjawaban pejabat lembaga negara baik ditingkat pusat maupun ditingkat daerah;

2. Berada dalam penguasaan, pengurusan, dan pertanggungjawaban Badan Usaha Milik Negara / Badan Usaha Milik Daerah, Yayasan, Badan Hukum, dan Perusahaan yang menyertakan Modal Negara, atau perusahaan yang menyertakan pihak ketiga berdasarkan perjanjian dengan negara.

c. Batasan mengenai perekonomian negara, menurut undang-undang tersebut adalah kehidupan pererkonomian yang disusun sebagai usaha bersama berdasarkan asas kekelurgaan atau usaha masyarakat secara mandiri yang didasarkan pada kebijakan pemerintah baik ditingkat pusat maupun ditingkat daerah sesuai dengan peraturan perundang-undangan yang berlaku yang bertujuan memberikan manfaat, kemakmuran dan kesejahtraan kepada seluruh kehidupan rakyat sesuai dengan perekonomian negara dalam Pasal 2 dan Pasal 3 Undang-Undang Nomor 39 Tahun 1999 sebagaimana telah diubah dengan Undang-Undang Nomor 20 Tahun 2001 Tentang Pemebrantasan Tindak Pidana Korupsi.

Undang-Undang tersebut bermaksud untuk mengantisipasi terjadinya penyimpangan

keuangan

atau

pererkonomian negara yang semakin canggih dan rumit, oleh karenanya tindak pidana korupsi yang diatur dalam undangundang ini dirumuskan seluas-luasnya sehingga meliputi perbuatan-perbuatan memperkaaya diri sendiri atau orang lain suatu korporasi secara melawan hukum.

$$
\text { Menurut Hasibuan, Albert }
$$

(1997). Korupsi sebagai fenomena penyimpangan dalam kehidupan sosial, budaya, kemasyarakatan, dan kenegaraan sudah sejak lama dikaji secara kritis oleh para ilmuwan dan filsuf. Filsuf Yunani, Aristoteles, yang diikuti oleh Machiavelli, misalnya, sejak awal sudah merumuskan sesuatu yang disebutnya sebagai korupsi moral (moral corrupt). Korupsi moral merujuk pada berbagai bentuk penyimpangan konstitusi, sehingga para penguasa rezim termasuk dalam sistem demokrasi tidak lagi dipimpin oleh hukum dan tidak lagi melayani kepentingan rakyat, tetapi tak lebih hanya berupaya melayani dirinya sendiri.

Korupsi bisa dilihat dari perspektif kebudayaan. Secara teoritis dan praktis, relasi antara korupsi dan kebudayaan sangat kuat. Bahkan dalam praktiknya, korupsi terkait dengan unsur tradisi feodalisme, hadiah, upeti, dan sistem kekerabatan (extended family). Korupsi agaknya akan tumbuh dalam masyarakat atau bangsa yang memiliki tradisi budaya feodalis atau neofeodalis. Pasalnya, dalam budaya tersebut, tidak ada sistem nilai yang memisahksan secara tajam antara milik publik (Negara) dengan milik pribadi bagi ruling class (elit penguasa). Sedangkan, sistem kekerabatan ikut mendorong nepotisme.

Menurut Semma, Mansyur (2008) hal 33. Dalam perspektif agama, korupsi juga dipandang sebagai suatu perbuatan yang sangat tercela. Dalamperspektif ajaran Islam, misalnya, Hafidhuddin menyatakan, korupsi termasuk perbuatan fasad atau perbuatan yang merusak kemaslahatan, kemanfaatan hidup, dan tatanan kehidupan. Pelakunya dikategorikan melakukan jinayah kubro (dosa besar). Dalam konteks ajaran Islam yang lebih luas, korupsi merupakan tindakan yang bertentangan dengan prinsip keadilan (al-'adalah), akuntabilitas (alamanah), dan tanggung jawab. Sebagai suatu gejala sosial yang rumit, korupsi tidak dapat dirumuskan dalam satu kalimat saja.

Page|172 
Yang mungkin dilakukan adalah membuat gambaran yang masuk akal mengenai gejala tersebut, agar dapat dipisahkan dari gejala lain yang bukan korupsi.

\section{Ciri-ciri Korupsi}

Perbuatan korupsi di manapun dan kapanpun akan selalu memiliki ciri khas. Dan ciri khas tersebut bisa bermacammacam, beberapa diantaranya adalah sebagai berikut:

a. Melibatkan lebih dari satu orang;

b. Korupsi tidak hanya berlaku di kalangan pegawai negeri atau anggota birokrasi negara, korupsi juga terjadi di organisasi usaha swasta.

c. Korupsi dapat mengambil bentuk menerima sogok, uang kopi, salam tempel, uang semir, uang pelancar, baik dalam bentuk uang tunai atau benda atau pun wanita;

d. Umumnya serba rahasia, kecuali sudah membudaya;

e. Melibatkan elemen kewajiban dan keuntungan timbal balik yang tidak selalu berupa uang;

f. Setiap tindakan korupsi mengandung penipuan, biasanya pada badan publik atau masyarakat umum;

g. Setiap perbuatan korupsi melanggar norma-norma tugas danpertanggungjawaban dalam tatanan masyarakat;

h. Di bidang swasta, korupsi dapat berbentuk menerima pembayaran uang dan sebagainya, untuk membuka rahasia perusahaan tempat seseorang bekerja, mengambil komisi yang seharusnya hak perusahaan.

\section{Jenis-jenis Korupsi}

Dari segi tipologi, korupsi dapat dibagi dalam tujuh jenis yang berbeda. Tujuh jenis itu adalah sebagai berikut:

1. Korupsi transaktif (transactive corruption)

Korupsi transaktif merujuk kepada adanya kesepakatan timbal-balik antara pihak pemberi dan pihak penerima demi keuntungan kedua belah pihak, dan dengan aktif diusahakan tercapainya keuntungan ini oleh kedua-duanya. Korupsi jenis ini biasanya melibatkan dunia usaha dan pemerintah, atau antara masyarakat dan pemerintah.

2. Korupsi yang memeras (extortive corruption)

Korupsi yang memeras adalah jenis korupsi di mana pihak pemberi dipaksa untuk menyuap guna mencegah kerugian yang sedang mengancam dirinya, kepentingannya, atau orang-orang dan hal-hal yang dihargainya.

\section{Korupsi investif (investive corruption)}

Korupsi investif adalah pemberian barang atau jasa tanpa ada pertalian langsung dengan keuntungan tertentu, selain keuntungan yang dibayangkan akan diperoleh di masa yang akan datang.

\section{Korupsi perkerabatan (nepotistic corruption)}

Korupsi perkerabatan atau nepotisme, adalah penunjukan yang tidak sah terhadap teman atau sanak saudara untuk memegang jabatan dalam pemerintahan, atau tindakan yang memberikan perlakuan yang mengutamakan mereka, dalam bentuk uang atau bentuk-bentuk lain, secara bertentangan dengan norma dan peraturan yang berlaku.

5. Korupsi defensif (defensive corruption)

Korupsi defensif adalah perilaku korban korupsi dengan pemerasan. Korupsinya adalah dalam rangka mempertahankan diri.

6. Korupsi otogenik (autogenic corruption), dan

Korupsi otogenik adalah jenis korupsi yang dilakukan seorang diri, dan tidak melibatkan orang lain. Misalnya, anggota DPR yang mendukung berlakunya sebuah undang-undang tanpa menghiraukan akibat-akibatnya, dan kemudian menarik keuntungan finansial dari pemberlakuan undang-undang itu, 
karena pengetahuannya tentang undang-undang yang akan berlaku tersebut.

\section{Korupsi dukungan (supportive corruption).}

Sedangkan, korupsi dukungan tidak secara langsung menyangkut uang atau imbalan langsung dalam bentuk lain. Tindakan-tindakan yang dilakukan adalah untuk melindungi dan memperkuat korupsi yang sudah ada. Tindakan menghambat seorang yang jujur dan cakap untuk menduduki jabatan strategis tertentu, misalnya, bisa dimasukkan dalam kategori ini.

Korupsi merupakan masalah yang sangat serius. Alinea pertama Penjelasan Umum UU Nomor 7 Tahun 2006 tentang Pengesahan United Nations Convention Against Corruption, 2003menyatakan: "Tindak pidana korupsi merupakan ancaman terhadap prinsip-prinsip demokrasi, yang menjunjung tinggi transparansi, akuntabilitas, dan integritas, serta keamanan dan stabilitas bangsa Indonesia. Oleh karena korupsi merupakan tindak pidana yang bersifat sistematik dan merugikan pembangunan berkelanjutan sehingga memerlukan langkah-langkah pencegahan tingkat nasional maupun internasional. Dalam melaksanakan pencegahan dan pemberantasan tindak pidana korupsi yang efisien dan efektif diperlukan dukungan manajemen tata pemerintahan yang baik dan kerjasama internasional, termasuk pengembalian aset-aset yang berasal dari tindak pidana korupsi."

Yang patut diperhatikan adalah pengaruh korupsi yang menular, yaitu bila korupsi menyerang seluruh sistem sosial sedemikian rupa, sehingga yang terjangkit adalah sistem secara total. Jadi, tidak terbatas pada bagian dan tempat-tempat tertentu, yang tidak mempengaruhi pusat sistem sosial dan negara yang vital.

\section{Bentuk Delik Korupsi}

Dalam praktek kita mengenal dua bentuk korupsi diantaranya Administrative Coruption, di mana segala sesuatu yang dijalankan adalah sesuai dengan hukum/ peraturan yang berlaku. Akan tetapi, individu- individu tertentu memperkaya dirinya sendiri. Misalnya dalam hal proses rekruitmen pegawai negeri, di mana dilakukan ujian seleksi mulai dari seleksi administratif sampai ujian pengetahuan atau kemampuan. Akan tetapi. Yang harus diluluskan sudah tertentu orangnya. Selain itu ada juga yang disebut dengan Against the rule corruption, artinya korupsi yang dilakukan adalah sepenuhnya bertentangan dengan hukum. Misalnya penyuapan, penyalahgunaan jabatan untuk memperkaya diri sendiri atau oarang lain atau suatu korporasi. Di masa orde lama masalah korupsi ini diperangi dengan Peraturan Penguasa Perang NomorPrt/Perpu/013/1958, yang diumumkan pada tanggal 16 April 1958 dan disiarkan dalam Berita Negara nomor 40 Tahun 1958.

Ada beberapa perumusan delik dalam tindak pidana korupsi diantaranya

adalah:

1. Memperkaya Diri atau Orang Lain Secara Melawan Hukum

Perumusan tindak pidana korupsi menurut pasal 2 ayat 1 Undang- Undang Nomor 31 Tahun 1999 adalah setiap orang (orang- perorangan atau korporasi) yang memenuhi unsur/ elemen dari pasal tersebut.dengan demikian, pelaku tindak pidana korupsi menurut pasal ini adalah "Setiap orang", tidak ada keharusan Pegawai Negeri. Jadi, juga dapat dilakukan oleh orang yang tidak berstatus sebagai pegawai negeri atau korporasi, yang dapat berbentuk badan hukum atau perkumpulan.

2. Melakukan Perbuatan Memperkaya diri sendiri atau orang lain atau Korporasi

Adapun perbuatan yang dilakukan menurut elemen ini adalah:

a. Memperkaya diri sendiri, artinya dengan perbuatan melawan hukum itu pelaku menikmati bertambahnya kekayaan atau harta benda miliknya sendiri.

b. Memperkaya orang lain, yaitu akibat perbuatan melawan hukum dari pelaku ada orang lain yang menikmati bertambahnya kekayaannya atau bertambahnya harta bendanya. Jadi yang diuntungkan bukan pelaku langsung.

c. Memperkaya korporasi, atau mungkin juga mendapat keuntungan dari perbuatan melawan hukum yang dilakukan oleh pelaku adalah suatu 
korporsi, yaitu kumpulan orang atau kumpulan kekeyaan yang terorganisasi, baik merupakan badan hukum maupun badan hukum (pasal 1 angka 1 Undang- undang Nomor 31 Tahun 1999).

3. Merugikan keuangan negara atau perekonomian Negara.

Apabila perbuatan itu dapat merugikan keuangan negara atau perekonomian negara, perbuatan pidana sudah selesai dan sempurna dilakukan.

\section{Penjatuhan pidana pada perkara tindak} pidana pada perkara tindak pidana korupsi

Berdasarkan ketentuan undang-undang nomor 31 Tahun 1999 sebagaimana telah diubah dengan undang-undang nomor 20 tahun 2001, jenis penjatuhan pidana yang dapat dilakukan hakim terhadap terdakwa tindak pidana korupsi adalah sebagai berikut.

\section{Pidana Mati}

Dapat dipidana mati karena kepada setiap orang yang secara melawan hukum melakukan perbuatan memperkaya diri sendiri atau orang lain atau suatu korporasi yang dapat merugikan keuangan Negara atau perekonomian Negara sebagaimana ditentukan dalam Pasal 2 ayat (1) Undang-undang nomor 31 tahun 1999 sebagaimana telah diubah dengan Undang-undang nomor 20 tahun 2001 tentang pemberantasan tindak pidana korupsi, yang dilakukan dalam keadaan tertentu.

\section{Pidana Penjara}

a. (Pasal 2 ayat 1)Pidana penjara seumur hidup atau pidana penjara paling singkat 4 (empat) tahun dan paling lama 20 (dua puluh) tahun dan denda paling sedikit Rp. 200.000.000,00 (dua ratus juta rupiah) dan paling banyak Rp. 1.000.000.000,00 (satu miliar rupiah) bagi setiap orang yang secara melawan hukum melakukan perbuatan memperkaya diri sendiri atau orang lain atau suatu korporasi yang dapat merugikan keuangan Negara atau perkonomian Negara.

b. (Pasal 3)Pidana penjara seumur hidup atau pidana penjara paling singkat 1 (satu) tahun dan/atau denda paling sedikit Rp. 50.000.000,00 (lima puluh juta rupiah) dan paling banyak satu Rp. 1.000.000.000,00 (satu miliar rupiah) bagi setiap orang yang dengan tujuan menguntungkan diri sendiri atau orang lain atau suatu korporasi, menyalahgunakan kewenangan, kesempatan, atau sarana yang ada padanya karena jabatan atau kedudukan yang dapat merugikan keuangan Negara atau perekonomian Negara.

c. (Pasal 21) Pidana penjara paling singkat 3 (tiga) tahun dan paling lama 12 (dua belas) tahun dan/atau denda paling sedikit Rp.150.000.000,00 (seratus lima puluh juta rupiah) dan paling banyak Rp. 600.000.000,00 (enam ratus juta) bagi setiap orang yang dengan sengaja mencegah, merintangi atau menggagalkan secara langsung atau tidak langsung penyidikan, penuntutan, dan pemeriksaan di siding pengadilan terhadap tersangka atau terdakwa ataupun para saksi dalam perkara korupsi.

d. (pasal 28, pasal 29, pasal 35, dan pasal 36) Pidana penjara paling singkat 3 (tiga) tahun dan paling lama 12 (dua belas) tahun dan/atau denda paling sedikit Rp. 150.000.000,00 (seratus lima puluh juta rupiah) dan paling banyak Rp. 600.000.000,00 (enam ratus juta rupiah) bagi setiap orang.

\section{Tindak Pidana yang dilakukan Oleh atau Atas Nama Suatu Korporasi}

Pidana pokok yang dapat dijatuhkan adalah pidana denda dengan ketentuan maksimal ditambah 1/3 (sepertiga). Penjatuhan pidana ini melalui procedural ketentuan pasal 20 ayat (1)(5) undang-undang 31 tahun 1999 tentang pemberantasan tindak pidana korupsi adalah sebagai berikut:

1. Dalam hal tindak pidana korupsi dilakukan oleh atau atas nama suatu korporasi, maka tuntutan dan penjatuhan pidana dapat dilakukan terhadap korporasi dan/atau pengurusnya.

2. Tindak pidana korupsi dilakukan oleh korporasi apabila tindak pidana tersebut dilakukan oleh orang baik berdasarkan hubungan kerja maupun berdasarkan hubungan lain, bertindak 
dalam lingkungan korporasi tersebut baik sendiri maupun bersama-sama.

3. Dalam hal ini tuntutan pidana dilakukan terhadap suatu korporasi maka korporasi tersebut diwakili oleh pengurus, kemudian pengurus tersebut dapat diwakilkan kepada orang lain.

4. Hakim dapat memerintahkan supaya pengurus korporasi menghadap sendiri di pengadilan dan dapat pula memerintahkan supaya penguruh tersebut dibawa ke siding pengadilan.

5. Dalam hal tuntutan pidana dilakukan terhadap korporasi, maka panggilan untuk menghadap dan menyerahkan surat panggilan tersebut disampaikan kepada pengurus di tempat tinggal pengurus atau ditempat pengurus berkantor.

\section{KESIMPULAN}

\section{Tindak Pidana Korupsi sebagai Tindak Pidana Khusus}

Kekhususan peraturan perundangundangan tindak pidana khusus, dari aspek norma, jelas mengatur hal-hal yang belum diatur dalam KUHP. Dikatakan khusus, karena dalam UU No 20 Tahun 2001 tentang Perubahan atas UU No 31 Tahun 1999 tentang Pemberantasan Tindak Pidana Korupsi terdapat asas atau hal - hal yang menyimpang dari ketentuan umum dalam Buku I KUHP.Contohnya perbedaan pada KUHP sebagai sumber hukum materiil pada tindak pidana umum dengan UU tindak pidana korupsi pada tindak pidana khusus:

\begin{tabular}{|c|c|c|c|}
\hline No & Perbedaan & KUHP & $\begin{array}{c}\text { UU Tindak } \\
\text { pidana } \\
\text { korupsi }\end{array}$ \\
\hline 1 & Penyadapan & $\begin{array}{c}\text { Tidak } \\
\text { dibolehkan }\end{array}$ & $\begin{array}{c}\text { Dibolehkan } \\
\text { dilakukan } \\
\text { penyadapan }\end{array}$ \\
\hline 2 & $\begin{array}{l}\text { Aparat } \\
\text { penegak } \\
\text { hukum }\end{array}$ & $\begin{array}{l}\text { Polisi sebagai } \\
\text { penyidik dan } \\
\text { penyelidik }\end{array}$ & \begin{tabular}{|c} 
Penyidik dan \\
penyelidik \\
selain polisi \\
juga bisa jaksa \\
penuntut \\
umum dan \\
penyidik KPK
\end{tabular} \\
\hline 3 & \begin{tabular}{|c|} 
Sistem \\
peradilannya
\end{tabular} & $\begin{array}{c}\text { Bersifat } \\
\text { konvensional }\end{array}$ & Secara ad hoc \\
\hline
\end{tabular}

\begin{tabular}{|c|c|c|c|}
\hline 4 & $\begin{array}{l}\text { Hukuman } \\
\text { Pokok }\end{array}$ & $\begin{array}{c}\text { - Pidana Mati } \\
\text { Pidana penjara } \\
\text { - Kurungan; } \\
\text { dan } \\
\text {-Denda. }\end{array}$ & $\begin{array}{l}\text { - Pidana mati } \\
\text { - Pidana } \\
\text { penjara } \\
\text { - Hukuman } \\
\text { denda }\end{array}$ \\
\hline 5 & $\begin{array}{l}\text { Hukuman } \\
\text { Percobaan, } \\
\text { pembantuan }\end{array}$ & $\begin{array}{c}\text { Percobaan, } \\
\text { pembantuan } \\
\text { tindak pidana } \\
\text { hukumannya } \\
\text { dikurangi } 1 / 3 \\
\text { dari ancaman } \\
\text { hukuman. } \\
\end{array}$ & $\begin{array}{l}\text { Percobaan, } \\
\text { pembantuan } \\
\text { tindak pidana } \\
\text { korupsi } \\
\text { dipidana sama } \\
\text { dengan pelaku }\end{array}$ \\
\hline 6. & $\begin{array}{l}\text { Ancaman } \\
\text { pidana }\end{array}$ & $\begin{array}{l}\text { Ancaman } \\
\text { pidana } \\
\text { maksimum }\end{array}$ & $\begin{array}{c}\text { Adanya pidana } \\
\text { minimum dan } \\
\text { maksimum }\end{array}$ \\
\hline 7 & $\begin{array}{l}\text { Subjek } \\
\text { Hukum }\end{array}$ & $\begin{array}{c}\text { Orang } \\
\text { perorangan }\end{array}$ & $\begin{array}{c}\text { Orang dan } \\
\text { Korporasi ( } \\
\text { Badan hukum } \\
\text { / bukan badan } \\
\text { hukum ). } \\
\end{array}$ \\
\hline
\end{tabular}

\section{TINJAUAN YURIDIS TERHADAP PUTUSAN PERKARANOMOR: 243 / PId.B / 2010 PN.LMG}

Akibat hukum bagi terdakwa yang berstatus kepala desa, yang dalam hal ini akan dikajiputusan Pengadilan Negeri Lamongan dalam perkara Nomor: 243 / Pid.B / 2010 / Pn.Lmg.

\section{Contoh Kasus Tindak Pidana Korupsi}

Sebelum mengkaji akibat hukum terhadap tindak pidana korupsi bagi terdakwa yang berstatus kepala desa, maka agar diperoleh gambaran konkret perlu dipaparkan contoh kasus dalam perkara nomor: 243 / PId.B / 2010 / PN.Lmg.

Berdasarkan dakwaan jaksa penuntut umum nomor : PDS-01/LAMON/ 07/ 2010, diperoleh tentang gambaran duduk perkara tindak pidana korupai sebagai berikut: "Bahwa terdakwa Ahmad Rozi, S.E,Bin Khayatun bersama-sama dengan Trubus Bin Kasjadi dan Moh. Amin Bin Katimin (masing-masing dalam BAP terpisah) atau masing-masing bertindak sendiri-sendiri. Sebagai Kepala Desa Jabung Kecamatan Laren, Kabupaten Lamongan dan sekaligus menjadi Anggota pengadaan P2T (Panitia Pengadaan Tanah) / panitia 9 Kabupaten. Lamongan dalam pelaksanaan pengadaan tanah untuk kepentingan umum yaitu proyek Jabung Ring Dyke LSRIP Phase II di Kabupaten Lamongan, atau setidaktidaknya di suatu tempat lain yang termasuk 
dalam daerah hokum Pengadilan Negeri Lamongan, dengan perbuatan melawan hokum melakukan perbuatan yang dapat merugikan keuangan Negara atau perekonomian Negara, sebesar kurang lebih Rp. 488.601.000.- (empat ratus delapan puluh juta enam ratus satu ribu rupiah).

Adapun perbuatan tersebut dilakukan dengan cara dan keadaan antara lain:

- Bahwa pada tahun 2009 di Desa Jabung Kecamatan Laren, Kabupaten Lamongan dilaksanakan pembebasan tanah untuk kepentingan umum yaitu proyek proyek Jabung Ring Dyke LSRIP Phase II, yang berlokasi di rawa Desa Jabung,. Untuk keperluan tersebut telah dilakukan pengukuran tanah sejak akhir tahun 2008 dan dilakukan pemberkasan sekitar bulan Juli 2009. Yang melaksanakan pengadaan tanah adalah Balai Besar Bengawan Solo, dan sumber dana untuk pembayaran santunan terhadap tanah seluas $590,387 \mathrm{~m}^{2}$ yang terkena proyek berasal dari APBD Kabupaten Lamongan dan APBN Tahun anggaran 2009;

- Bahwa untuk pemberian uang santunan bagi penggarap tanah Negara, pihak Balai Besar Bengawan Solo telah mencairkan dana yang bersumber dari APBD Kabupaten Lamongan sebesar Rp. 2.756.853.000.- (dua milyar tujuh ratus lima puluh enam juta delapan ratus lima puluh tiga ribu rupiah) untuk santunan penggarap Tanah Negara seluas 306.117 $\mathrm{m}^{2}$. Selain dari APBD Kab. Lamongan dana yang dicairkan juga berasal dari APBN sebesar 2.558.430.000.- (dua milyar lima ratus lima puluh delapan juta empat ratus tiga puluh ribu rupiah) untuk santunan penggarap Tanah Negara seluas $284.270 \mathrm{~m}^{2}$. Jumlah keseluruhan dana baik dari APBD maupun APBN sebesar Rp.5.316.263.000,-- (lima milyar tiga ratus enam belas juta dua ratus enam puluh tiga ribu rupiah) pembayaran santunan tersebut dilakukan pada tanggal 17 Desember 2009, untuk tahap awal, yang kedua dilaksanakan pada tanggal 6 Mei 2010;

- Bahwa sebelum realisasi ganti rugi dan santunan dilaksanakan, telah dilakukan sosialisasi oleh P2T (panitia pengadaan tanah) / panitia $9 \mathrm{Kab}$. Lamongan, yang menjelaskann bahwa dasar penerimaan santunan tanah Negara adalah surat pernyataan penggarap, surat keterangan tanah dari Kepala Desa, surat pernyataan penguasaan fisik sebidang tanah dan kartu tanda penduduk sesuai dengan Surat Keputusan Bupati nomor: 188/213.1/Kep/413.13/2009 tanggal 17 Juli 2009 tentang penetapan besarnya uang ganti rugi bagi yang terkena Proyek Jabung Ring Dyke LRSIP Phase II dan petunjuk pelaksanaan pengadaan tanah bagi pembangunan untuk kepentingan umum dan P2T Kab. Lamongan nomor: 4/01/P2T/2009 Tanggal 1 juli 2009;

- Bahwa Proyek Jabung Ring Dyke LRSIP Phase II tahun 2009, yang membebaskan tanah hak milik (tanah yayasan) dan Negara (tanah bonorowo) sudah direncanakan sejak masa pemerintahan Kades lama (Alm. KASWANTO), dengan tujuan untuk bisa menerima ganti rugi terhadap tanah negara yang dibebaskan. Pada masa kades lama telah ada pemikiran untuk mendapatkan santunan atas tanah negara dirawa Desa Jabung tersebut. Oleh (Alm. KASWANTO) telah dipersiapkan SPPT PBB sebagai dasar kepemilikan. Kebijakan tersebut dilanjutkan oleh terdakwa Ahmad Rozi, S.E,Bin Khayatun sehingga keseluruhan berkas SPPT PBB yang terbit adalah untuk 33 orang penggarap;

- Bahwa dalam proses pengajuan berkas permohonan ganti rugi dan santunan untuk tanah Negara dirawa Desa Jabung yang diajukan kepada Balai Besar Bengawan Solo selaku pelaksana proyek Jabung Ring Dyke LRSIP Phase II tahun 2009, terjadi penyimpangan yang dilakukan oleh terdakwa Ahmad Rozi, S.E,Bin Khayatun;

- Bahwa status tanah yang dimohonkan SPPT PBB 33 orang adalah berstatus tanah Negara yang sesuai dengan ketentuan dalam pasal 3 ayat (1) huruf c UU nomor 12 tahun 1985 yang diubah dengan UU nomor 12 tahun 1994, adalah tidak dibebani suatu hak, terhadap tanah negara tersebut juga juga belum pernah dilakukan peralihan hak, sehingga penerbitan SPPT PBB yang dilakukan Kades lama (Alm. KASWANTO) maupun Ahmad Rozi, S.E,Bin Khayatun adalah dengan permohonan tidak procedural;

- Bahwa dengan dasar SPPT PBB yang dimiliki oleh 33 orang warga Desa Jabung, terdakwa mengajukan proses pengajuan permohonan santunan atas tanah Negara dengan membuat dan memproses pemberkasan sebagai syarat untuk dapat menerima santunan. Blankoblanko pemberkasan diperoleh dari BPN 
Lamongan. Selanjutnya terdakwa bersama-sama dengan Trubus Bin Kasjadi dan Moh. Amin Bin Katimin (masing-masing dalam BAP terpisah), mengisi blanko-blanko tersebuit sesuai dengan nama 33 orang yang namanya tercantum dalam SPPT PBB;

- Bahwa dalam kepemilikan SPPT PBB tersebut terdapat nama-nama yang sebenarnya bukan sebagai penggarap Tanah Negara dan juga bukan warga asli Desa Jabung. Akan tetapi oleh terdakwa dinyatakan bahwa 33 nama yang tercantum seolah-olah seseluruhnya adalah penggarap Tanah Negara (Banorowo) dan warga asli DesaJabung oleh terdakwa dimohonkan 33 orang sesuai dengan SPPT PBB, selebihnya 6 SPPT PBB dibuat pada masa jabatanterdakwa sebagai Kepala Desa Jabung;

- Untuk melengkapi berkas pengajuan permohonan santunan Tanah Negara yang syaratnya mengacu pada ketentuan Surat Keputusan Bupati Nomor 188/ 213.1/ Kep/ 413.013/ 2009 tanggal 17 Juli 2009 dan petunjuk Pelaksanaan Pengadaan Tanah Bagi Pembangunan Untuk Kepentingan Umum dari panitia Pengadaan Tanah Kabupaten lamongan Nomor: 04/01/P2T/2009 tanggal 01 Juli 2009, terdakwa Ahmad Rozi, S.E,Bin Khayatun bersama-sama dengan Trubus Bin Kasjadi dan Moh. Amin Bin Katimin (masing-masing dalam BAP terpisah) melakukan pengisian blanko-blanko berupa surat pernyataan penggarap, surat keterangan status tanah, surat pernyataan fisik biding tanah dan surat keterangan tanah atas nama para pemohon (33 orang) yang diajukan sebagai penggarap, sementara dalam kenyataannya beberapa diantara mereka bukan penggarap sebenarnya dan bukan warga Desa Jabung, namun oleh Terdakwa mereka dinyatakan sebagai penggarap yang sebenarnya. Blanko-blanko ditandatangani dan diketahui oleh terdakwa selaku Kepala Desa yang mengetahui keadaan senyatanya dilapangan. Pemohon santunan Tanah Negara tidak ada yang mengisi blanko sendiri yang harus dilampirkan dalam berkas permohonan santunan karena beberapa blanko telah diisikan oleh Terdakwa Ahmad Rozi, S.E,Bin Khayatun bersama-sama dengan Trubus Bin Kasjadi dan Moh. Amin Bin Katimin dan dibubuhi materai. Sebagian dari blanko-blanko surat Pernyataan yang telah diisi tersebut diatas, ada yang tidak ditandatangani pemohon sendiri;

- Bahwa selanjutnya pihak BPN menginventarisisr permohonan yang diajukan oleh 33 pemohon dari Desa Jabung, dengan melakukan cross check kepada terdakwa untuk keabsahan berkas permohonan yang diajukan oleh para pemohon. Terdakwa selaku Kepala Desa dan koordoinator pemberkasan, memberikan persetujuan terhadap kebenaran isi permohonan tersebut. Berkas yang sudah lengkap oleh BPN kemudian diserahkan ke Balai Besar Bengawan Solo untuk melengkapi persyaratan pencairan santunan tanah Negara;

- Bahwa pencairan uang santunan tahap pertama dilaksanakan 2 kali yaitu pada bulan Oktober 2009 dan Desember 2009, pada waktu pelaksanaan pencairan pihak BPN maupun Balai Besar Bengawan Solo melakukan check ulang terhadap para calon penerima uang santunan tanah Negara, dan oleh terdakwa nama-nama penerima santunan uang Negara telah dibenarkan;

- Bahwa penerima uang santunan tersebut merasa bahwa santunan yang mereka terima adalah sah dan menjadi hak mereka sebagai pemilik SPPT PBB. Para pemohon sebelumnya tidak tahu siapa saja yang menerima santunan tanah Negara, mengingat segala pemberkasan permohonan dibuatkan oleh terdakwa Trubus Bin Kasjadi dan Moh. Amin Bin Katimin;

- Bahwa sebelum realisasi pencairan santunan dan ganti rugi, ada komitmen antara kepala Desa (terdakwa), BPD, dan penerima uang santunan tanah Negara, yang menyatakan para penerima uanag santunan dikenakan peotongan sejumlah $30 \%$ dari nilai uang santunan yang diterima, dengan alas an untuk pembangunan Desa. Pemotongan tersebut sempat dilaksanakan namun masyarakat mempermasalahkannya, potongan tersebut sebagian dikembalikan lagi kepada para penerima santunan;

- Bahwa selain dari 33 nama pemeganag SPPT PBB yang diajukan permohonan santunan tanah Negara oleh terdakwa, seharusnya wargaa Desa Jabung yang senyatanya memang menggarap tanah Negara yang terkena proyek adalah yang lebih berhak atas penerimaan santunan tanah Negara, walaupun tanpa dibuktikan 
dengan penguasaan SPPT PBB. Karena sesuai dengan petunjuk pelaksanaan Pengadaan Tanah bagi pembangunan untuk kepentingan umum nomor: 04/01/P2T/2009 tanggal 01 Juli 2009, SPPT PBB bukan syarat mutlak pengajuan pencaiaran santunan atas tanah Negara, tetap bisa dilaksanakan selama ada pngajuan permohonan dari penggarap. Dengan kata lain apabila senyatanya memang menggarap tanah Negara walaupun tidak memiliki SPPT PBB, penggarap tanah Negara dapat mengusulkan permohonan atas santunan tanah Negara yang digarap olehnya dengan persetujuan dan diketahui oleh Kepala Desa, karena sesuai dengan tujuan pemberian santunan tanah Negara adalah untuk meningkatkan kesejahteraan penggarap tanah Negara;

- Bahwa diantara 33 orang penerima santunan bagi penggarap tanah Negara, salah satu diantaranya adalah terdakwa sendiri dengan dasar SPPT PBB atas namanya, terdakwa membuat surat pernyataan selaku penggarap tanah Negara $540289 \mathrm{~m} 2$, berdasarkan surat pernyataan penguasaan fisik bidang tanah tertanggal 29 Juli 2009, (dikuatkan dengan surat keterangan tanah dari kepala desa nomor: 470.07/413.349/10/2009, ditanda tangani terdakwa sendiri) dan surat pernyataan selaku penggarap tanggal 16 September 2009 9dikuatkan dengan surat keterangan penguasaan tanah dari Kades Nomor: 470.85/413.349/10/2009, yang ditanda tangani terdakwa sendiri), sehingga seolah-olah terdakwa sebagai seorang yang berhak menerima uang santunan atas Tanah Negara sebesar Rp. 488.601.000,- (empat ratus delapan puluh delapan juta enam ratus satu ribu rupiah), padahal dalam kenyataannya terdakwa bukanlah penggarap tanah Negara seluas itu,baik secara langsung maupun dikerjakan oleh orang lain.

- Akibat terdakwa Ahmad Rozi, S.E,Bin Khayatun selaku Kepala Desa Jabung Kecamatan Laren Kabupaten Lamongan melakukan perbuatan memperkaya diri sendiri atau oaring lain atau suatu koorperasi, melaksanakan pemberkasan permohonan santunan untuk penggarap tanah Negara tidak sesuai dengan ketentuan, menyebabkan uang santunan pembebasan Tanah Negara Tanah Negara dari Balai Besar Bengawan Solo untuk pengadaan tanah bagi kepentingan umum untuk melaksanakan proyek Jabung Ring Dyke Phase II tahun 2009, tidak dapat terlaksana dengan baik karena sebagian anggarannya dipergunakan untuk kepentingan orang lain dan kepentyingan terdakwa serndiri, sehingga berakibat merugikan Negara senilai Rp. 488.601 .000 (empat ratus delapan puluh delapan juta enam ratus satu ribu rupiah), atau setidak-tidaknya sekitar sejumlah itu.

Perbuatan terdakwa sebagaimana diatur dan diancam pidana dalam Pasal 2 juncto pasal 18 ayat (1) huruf b Undang-Undang Nomor 31 tahun 1999 tentang pemberantasan tindak pidana korupsi sebagaimana telah diperbaharui dengan UU Nomor 20 tahun tahun 2001 pasal 55 ayat (1) KUHP

Analisis Akibat Hukum Bagi Terdakwa Tindak Pidana Korupsi Yang Berstatus Kepala Desa, Dalam Putusan Perkara Pidana Nomor: 243 / PId.B / 2010 / PN.LMG

Dalam putusan perkara pidana Nomor : 243 / PId.B / 2010 / PN.Lmg, majelis hakim Pengadilan Negeri Lamongan telah menjatuhkan pidana kepada terdakwa (Ahmad Rozi, S.E,Bin Khayatun) ROZI, S.E,Bin KHAYATUN tersebut diatas dengan pidana penjara selama 4 (empat) tahun dan denda sebesar Rp. 200.000.000,(dua ratus juta rupiah) dengan ketentuan apabila denda tesebut tidak dibayar maka harus diganti dengan pidana kurungan selama 3 (tiga) bulan, serta membayar uang pengganti sebesar Rp. 488.601.000,- (empat ratus delapan puluh delapan juta enam ratus satu ribu rupiah), dengan ketentuan apabila dalam waktu 1 (satu) bulan setelah putusan hakim mempunyai kekuatan hukum tetap, maka harta bendanya dapat disita dan dilelang untuk menutupi uang pengganti, namun jika terdakwa tidak mempunyai harta benda yang mencukupi untuk membayar uang pengganti, namun jika terdakwa tidak mempunyai harta benda yang mencukupi untuk membayar uang pengganti maka diganti dengan pidana penjara selama 1 (satu) tahun;

Hal ini dengan mendasarkan argumen sebagai berikut:

1. Asas legalitas

Asas legalitas ini ketentuannya terdapat dalam Pasal 1 ayat (1) KUHP yang menyebutkan bahwa suatu perbuatan 
tidak dapat dipidana kecuali berdasarkan ketentuan perundang-undangan pidana yang telah ada.

Pengertian pokok yang terkandung dalam asas legalitas adalah sebagai berikut :

a. Tidak ada perbuatan yang dilarang dan diancam dengan pidana apabila hal itu sebelumnya tidak dinyatakan dengan tegas dalam suatu ketentuan undang-undang.

b. Untuk menentukan adanya tindak pidana tidak boleh digunakan analogi.

c. Ketentuan hukum pidana tidak boleh berlaku surut.

2. Kesalahan

Seseorang yang melakukan tindak pidana tidak selalu dapat dipidana. Dengan kata lain dipidananya seseorang tidak cukup hanya apabila orang itu telah melakukan perbuatan yang bertentangan dengan hukum atau bersifat melawan hukum.

"Jadi, meskipun perbuatannya memenuhi rumusan delik dalam undangundang dan tidak dibenarkan (an objective breach of a penal provission) namun hal tersebut belum menenuhi syarat untuk penjatuhan pidana".

Dengan demikian, hal tersebut tergantung dari apakah orang itu dalam melakukan tindak pidana mempunyai kesalahan atau tidak. Sebab untuk menjatuhkan pidana terhadap seseorang tidak cukup telah dilakukannya tindak pidana saja, tetapi harus pula memenuhi adanya syarat bahwa orang yang melakukan perbuatan tersebut mempunyai kesalahan atau bersalah. Dengan perkataan lain, orang tersebut dapat dipertanggungjawabkan atas perbuatannya.

\section{DAFTAR PUSTAKA}

Martiman

Prodjohamidjojo,

1984.Komentar atas Kitab Undang-

Undang Hukum Acara Pidana

(KUHAP), Jakarta,Pradnya Paramitha.

Tb. Ronny Rahman Nitibaskara, 2007.Tegakkan Hukum Gunakan

Hukum. Jakarta: Grafindo Persada.

Andi Hamzah, 2006. Pemberantasan

Korupsi Melalui Hukum Pidana
Nasional dan Internasional. Jakarta: Raja Grafindo Persada.

Darwan

Prinst,

S.H. 2000. Pemberantasan Tindak Pidana Korupsi. Bandung : PT. Citra Aditya Bakti.

Leden Marpaung, 1996.Kejahatan Terhadap Kesusilaan dan Masalah Prevensinya, Sinar Grafika, Jakarta.

Chidir Ali, Badan Hukum, Alumni, Bandung, 1991.

Andi Hamzah, 2007.pemberantasan korupsi melaluihokum pidana Nasional dan internasional, PT RajaGrafindo Persada, Jakarta.

R. Wiyono, SH, 2008. pembahasan Undang-undang Pemberantasan Tindak Pidana Korupsi. Sinar Grafika, Jakarta, Edisi kedua, cet. Pertama, Juni.

Sudarto, 1990.Hukum Pidana I, Fakultas Hukum UNDIP, Semarang.

Salinan Dokumen :

$\begin{array}{cc}\text { Putusan } & \text { Perkara } \\ \text { 243/Pid.B/2010/PN.Lmg. }\end{array}$

